\title{
Experimentally induced marine flexibacteriosis in Atlantic salmon smolts Salmo salar. I. Pathogenicity
}

\author{
Rebecca van Gelderen ${ }^{1, *}$, Jeremy Carson ${ }^{2}$, Barbara Nowak ${ }^{1}$ \\ ${ }^{1}$ National Centre for Marine Conservation \& Resource Sustainability, University of Tasmania, Locked Bag 1370, Launceston, \\ Tasmania 7250, Australia \\ ${ }^{2}$ Fish Health Laboratory, Tasmanian Aquaculture and Fisheries Institute, Department of Primary Industries and Water, \\ PO Box 46, Kings Meadows, Tasmania 7249, Australia
}

\begin{abstract}
Tenacibaculum maritimum causes marine flexibacteriosis in many cultured fish species, including Atlantic salmon Salmo salar in Tasmania, Australia. Several aspects of the pathogenicity of this bacterium were investigated in naive Atlantic salmon smolts using different isolates, growth conditions and doses to produce a model of infection. We found that T. maritimum is pathogenic to Atlantic salmon using either marine Shieh's or marine Ordal's culture medium. The use of aeration in broth culture produced a dose effect in challenge due to a 'clumping' of the bacteria during culture. The virulence of a strain appears to be connected with this 'clumping'; the more adherent the cells, the more pathogenic the strain. Differences in virulence between 3 strains was apparent, with 1 of the strains (89/4747) being non-pathogenic and unable to produce disease in the host. The 2 other strains (89/4762, 00/3280) were highly virulent, resulting in $100 \%$ mortalities within 3 d. A reproducible model of infection has been established in the present study using strain 89/4762. Results from the present study provide a better insight into the nature of the disease.
\end{abstract}

KEY WORDS: Tenacibaculum maritimum $\cdot$ Pathogenicity $\cdot$ Atlantic salmon $\cdot$ Infection model

\section{INTRODUCTION}

Knowledge of the pathogenicity of an organism is essential for understanding the disease it causes. Pathogenicity is the ability of bacteria to produce disease in a host organism, and bacteria express pathogenicity via virulence, which refers to the degree of damage to the host (Alcamo 1983). The interaction between a pathogen and its host is dynamic as both are able to modify the activities and functions of the other. Infection of the host will depend not only on virulence of the pathogen, but also on infectivity of the pathogen and susceptibility of the host (Madigan \& Martinko 2003).

Tenacibaculum maritimum is the causative agent of marine flexibacteriosis in a number of cultured fish species worldwide (Wakabayashi et al. 1986, Devesa et al. 1989, Bernardet et al. 1990, Chen et al. 1995, Kusuda \& Kawai 1998, Ostland et al. 1999). In Tasmania, Australia, the disease has affected Atlantic salmon
Salmo salar, rainbow trout Oncorhynchus mykiss, greenback flounder Rhombosolea tapirina and striped trumpeter Latris lineata (Handlinger et al. 1997). Previous work has investigated similarities and differences in characteristics amongst bacterial isolates of T. maritimum (van Gelderen 2007).

After examining the different physical characteristics of various isolates, it was necessary to determine their effect on their host, i.e. what the differences in pathogenicity are between isolates with similar or different characteristics. The development of infection models under different parameters (growth conditions, strains and doses) should also provide insight into the nature of the pathogen.

The aims of the present study were to examine the pathogenicity in Salmo salar of different isolates of Tenacibaculum maritimum and to investigate the effects of different growth conditions, as well as to establish a model of infection. 


\section{MATERIALS AND METHODS}

Pathogenicity experiments. Three different methods were used to assess the pathogenicity of Tenacibaculum maritimum in Atlantic salmon (Table 1). Expt 1 was a comparison of methods: 2 different growth media, marine Shieh's broth (MSB) and marine Anacker and Ordal's broth (Anacker \& Ordal 1959) (MOB), with or without aeration were used during culture of bacteria. The assessment was made with strain 89/4762. Expt 2 was a comparison of the pathogenicity of 3 strains (89/4762, 89/4747,00/3280) and Expt 3 compared dose effects for 1 strain (89/4762). Assessments of culture media and strains on pathogenicity were made in a semi-static experiment. As a recirculation system was used in Expt 3, there were 2 different control treatments. One control treatment was within the recirculation system and was called control (in); and another was still part of the system but had a separate water source, and was called control (out). The system was set up with a filter bank down to $0.8 \mu \mathrm{m}$ for incoming water and $2 \mathrm{UV}$ lights $\left(400 \mathrm{~J} \mathrm{~m}^{2-1}, 4000 \mathrm{l} \mathrm{h}^{-1}\right)$ to reduce bacterial load.

Experimental fish. Naive, disease-free Atlantic salmon smolts were obtained from a commercial hatchery. The fish were initially kept in freshwater and then acclimated to seawater (salinity 35) over a week starting at salinity 5 . They were fed on a commercial diet (Atlantic HP, Skretting) at maintenance ( $1 \%$ body weight) during acclimation. Feeding ceased $48 \mathrm{~h}$ before challenge. Numbers of fish and replicates,

Table 1. Tenacibaculum maritimum. Methods employed to assess pathogenicity using bath challenge

\begin{tabular}{|c|c|c|c|c|}
\hline Expt & Isolate & $\begin{array}{c}\text { Dose } \\
\left(\text { cells } \mathrm{ml}^{-1}\right)\end{array}$ & Method & $\begin{array}{l}\text { Tanks (total no. and } \\
\text { type) }\end{array}$ \\
\hline 1 & $89 / 4762$ & $1 \times 10^{7}$ & Bath & $10 \times 1001$ semi-static \\
\hline 2 & $\begin{array}{l}89 / 4762 \\
89 / 4747 \\
00 / 3280\end{array}$ & $1 \times 10^{7}$ & Bath & $8 \times 2001$ semi-static \\
\hline 3 & $89 / 4762$ & $\begin{array}{l}1 \times 10^{5}, 1 \times 10^{6} \\
1 \times 10^{7}, 1 \times 10^{8}\end{array}$ & $\begin{array}{l}\text { Bath } \\
\text { system }\end{array}$ & $12 \times 2001$ recirculation \\
\hline
\end{tabular}

weight and length of the fish, and water conditions for each experiment are summarised in Table 2.

Bacteria cultures. Three strains of Tenacibaculum maritimum, 2 collected from Atlantic salmon (89/ $4762,89 / 4747)$ and 1 from rainbow trout (00/3280), were used in the present study. Stock cultures were stored frozen at $-80^{\circ} \mathrm{C}$ in single-use cryovials. Bacteria were initially cultured on marine Shieh's agar (MSA) at $25^{\circ} \mathrm{C}$ for $24 \mathrm{~h}$ and used as inoculum in $500 \mathrm{ml}$ (in a 21 glass conical flask) of MSB at room temperature $\left(20^{\circ} \mathrm{C}\right)$ for another $48 \mathrm{~h}$. The culture was decanted and washed 3 times in $0.2 \mu \mathrm{m}$ sterile filtered seawater by centrifugation at $3000 \times g$ for 30 min.. Cell concentration was estimated using a spectrophotometer at $550 \mathrm{~nm}$. The relationship between optical density and number of cells $\mathrm{ml}^{-1}$ was established in earlier growth studies of the bacteria through comparisons with direct cell counts (R. van Gelderen unpubl.). The only variation to this method was in Expt 1, where MOB was compared to MSB to grow strain 89/4762. Each medium was also divided into 2 treatments in Expt 1: with and without aeration. In the treatment with aeration, air was supplied by an air pump without a diffuser through a $0.2 \mu \mathrm{m}$ filter at a rate of $120 \mathrm{l} \mathrm{h}^{-1}$. In the treatment without aeration, the 21 conical flask was placed on an orbital shaker $(90 \mathrm{rpm})$ with no addition of air.

Challenge procedures. Fish were bath-challenged in $100 \mathrm{l}$ semi-static tanks in seawater of salinity 35 for $1 \mathrm{~h}$ before being randomly distributed into assigned tanks.

Sampling procedures. All investigations were carried out under the Australian Code of Practice for the Care and Use of Animals for Scientific Purposes 1997 and the Tasmanian Animal Welfare Act 1993. Approval was given by the University of Tasmania's Animal Ethics Committee under project no. A0007722. This approval was given under the stipulation that fish should be collected for examination when the first signs of physiological disturbance were evident. Physiological disturbances were defined to occur when a

Table 2. Salmo salar. Fish information and water parameters for each experiment

\begin{tabular}{|c|c|c|c|c|c|c|c|}
\hline \multirow[t]{2}{*}{ Expt } & \multirow{2}{*}{$\begin{array}{c}\text { No. of fish } \\
\text { (tank replicates) }\end{array}$} & \multicolumn{2}{|c|}{- Weight $(g)-$} & \multicolumn{2}{|c|}{ — Length $(\mathrm{cm})-$} & \multirow{2}{*}{$\begin{array}{l}\text { Water temp. } \\
\qquad\left({ }^{\circ} \mathrm{C}\right)\end{array}$} & \multirow[t]{2}{*}{ Salinity } \\
\hline & & Mean & Range & Mean & Range & & \\
\hline 1 & $8(2)$ & 86.2 & $29.2-150.8$ & 23.5 & $14.5-25.2$ & 16.5 & 35 \\
\hline 2 & $15(2)$ & 72.4 & $14.6-214.6$ & 19.1 & $11.7-27.6$ & 18.5 & 35 \\
\hline 3 & $15(3)$ & 88.1 & $47.6-138.3$ & 20.9 & $16.2-23.9$ & 18.0 & 35 \\
\hline
\end{tabular}


fish was unable to control its position in the water column and/or when erosive lesions were apparent. This is a state from which fish were unlikely to recover. For the most part, fish were euthanised before mortality occurred but this was not always possible. For the purpose of the present paper the term mortality is used to be consistent with the literature, even though morbidity would be a more accurate description.

Fish were checked 3 times $\mathrm{d}^{-1}$ for mortality and those affected were anaesthetised using clove oil (0.03 $\mathrm{ml} \mathrm{l}^{-1}$ seawater). The experiment was concluded when there were 3 consecutive days of no mortalities. All fish were examined bacteriologically by culturing skin lesions or sites of erosion on plates of MSA containing $4 \mu \mathrm{g} \mathrm{ml}^{-1}$ neomycin sulphate (Pazos et al. 1996). Smears $(1 \times 1 \mathrm{~cm})$ were prepared for staining by Gram's method and by immunofluorescence (IFAT). Cultures were incubated at $25^{\circ} \mathrm{C}$ for $2 \mathrm{~d}$ and the colonial morphology typical of Tenacibaculum maritimum was recorded.

Case definition. The criteria for accepting that fish were infected with marine flexibacteriosis involved 2 parts: recovery and quantification of colonies and cells. Tenacibaculum maritimum was recovered from mortalities by culture and in smears by IFAT as these methods are more specific than Gram stain. The minimum abundance of cells required for a positive result was 10 to 50 bacteria per 25 fields of view for IFAT and Gram stain (40× magnification). The minimum abundance required to record a positive result in culture was growth of colonies extending to the first streaking lines (Howard 1995).

Survivors. Any fish surviving at the end of the challenge period were euthanised using an overdose of clove oil (0.06 $\mathrm{ml} \mathrm{l}^{-1}$ seawater).

IFAT. We followed the procedure described by Carson et al. (1992). Smears taken from samples were initially air-dried and heat-fixed. The smears were overlaid with $40 \mu \mathrm{l}$ of rabbit anti-Tenacibaculum maritimum 89/0329-5 (DPIW) diluted 1:100 in phosphate buffered saline (PBS) (pH 7.2, $0.1 \mathrm{M}$ ) and incubated in a moist chamber for $30 \mathrm{~min}$ at $37^{\circ} \mathrm{C}$ before rinsing in PBS for $15 \mathrm{~min}$. After the removal of excess buffer by blotting, $20 \mu \mathrm{l}$ of anti-rabbit fluorescein isothiocyanate (FITC) (Silenus) diluted 1:60 in PBS was added to each slide. Smears were incubated at $37^{\circ} \mathrm{C}$ for $30 \mathrm{~min}$ and rinsed for $30 \mathrm{~min}$ in $\mathrm{PBS}$, which was replaced every $10 \mathrm{~min}$. Slides were mounted using alkaline glycerol buffer (Johnson \& Munday 1993), cover-slipped and examined at $40 \times$ magnification with epifluorescent microscopy using UV illumination.

Statistical analysis. Data were analysed using Kaplan-Meier survival analysis and a pair-wise comparison over strata with a Bonferroni correction of $\mathrm{p}$ values using SPSS 11.5 for Windows.

\section{RESULTS}

\section{Expt 1}

Fish challenged with Tenacibaculum maritimum strain 89/4762 grown in either MOB or MSB with aeration had cumulative mortalities of 93.75 and $87.5 \%$, respectively (Fig. 1). The MSB-grown bacteria produced mortalities in a shorter amount of time than those grown in MOB. Fish infected with MOB-grown bacteria, however, had a higher mortality rate. $T$. maritimum grown in either MOB or MSB without aeration both caused similar mortality profiles and reached cumulative mortality rates of 68.75 and $73.3 \%$, respectively, within the $10 \mathrm{~d}$ experimental period (Fig. 1). There were no mortalities in the control treatment. Pair-wise comparison showed a statistical difference between the control treatment and all challenge treatments $(p \leq 0.005)$. There was no significant difference between all challenge treatments (i.e. no significant difference between all $\mathrm{MOB}$ and MSB cultures) even though a distinct divergence in mortalities appeared between bacteria grown with and without aeration.

Methods to detect the presence of Tenacibaculum maritimum showed that plate culturing was less sensitive than Gram staining or IFAT (Table 3). Marine Shieh's culture plates containing $4 \mu \mathrm{g} \mathrm{ml}^{-1}$ neomycin sulphate were used to select for T. maritimum and while growth of other organisms was rarely observed, a lack of growth of any bacteria on the plates was more common.

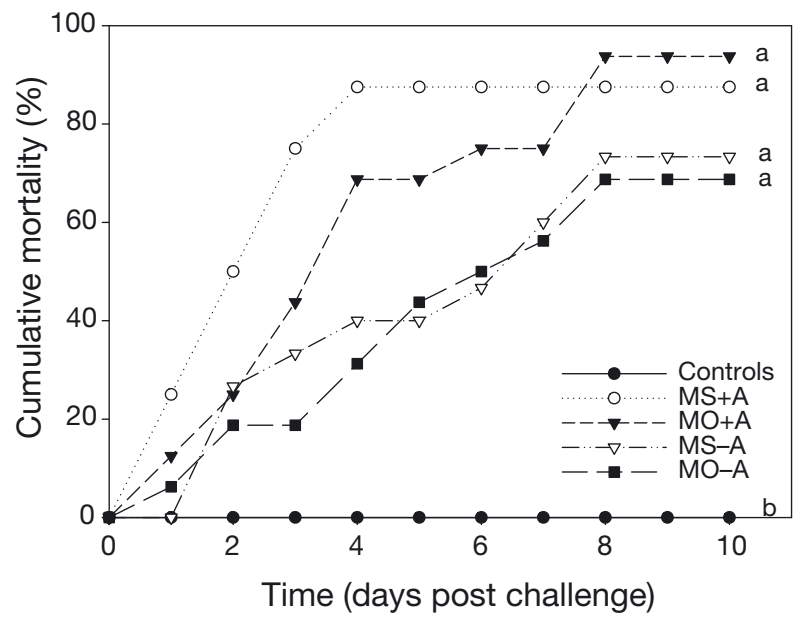

Fig. 1. Salmo salar. Expt 1. Cumulative mortality of Atlantic salmon challenged with Tenacibaculum maritimum strain 89/4762 grown on different media and under different aeration conditions. MS: marine Shieh's medium; MO: marine Ordal's medium; +A: with aeration; - A: without aeration. Lines with different letters are significantly different $(\mathrm{p} \leq 0.005)$ 
Table 3. Tenacibaculum maritimum in Salmo salar. Expt 1. Percentage of positive results relative to the number of fish tested by media culture, Gram stain and immunofluorescence (IFAT). Treatment: MS = marine Shieh's medium, MO $=$ marine Ordal's medium,$+\mathrm{A}=$ with aeration, $-\mathrm{A}=$ without aeration. Lesion: $+=$ present $_{,}-=$absent

\begin{tabular}{|lcccc|}
\hline Treatment & $\begin{array}{c}\text { Culture (\%), } \\
\text { mean } \pm \text { SE }\end{array}$ & $\begin{array}{c}\text { Gram (\%), } \\
\text { mean } \pm \text { SE }\end{array}$ & $\begin{array}{c}\text { IFAT (\%), } \\
\text { mean } \pm \text { SE }\end{array}$ & Lesion \\
\hline MS-A & $58.3 \pm 8.3$ & $83.3 \pm 16.6$ & $100 \pm 0$ & + \\
MO-A & $78.6 \pm 7.1$ & $92.8 \pm 7.1$ & $92.8 \pm 7.1$ & + \\
MS+A & $66.9 \pm 4.6$ & $100 \pm 0$ & $93.3 \pm 6.2$ & + \\
MO+A & $78.6 \pm 7.1$ & $92.8 \pm 7.1$ & $100 \pm 0$ & + \\
Control & $0 \pm 0$ & $0 \pm 0$ & $0 \pm 0$ & - \\
\hline
\end{tabular}

\section{Expt 2}

Mortalities reached $100 \%$ for fish challenged with Tenacibaculum maritimum strains 00/3280 and 89/4762 within $3 \mathrm{~d}$ of the challenge (Fig. 2). On the second day, strain $00 / 3280$ led to mortalities of $81.4 \%$ and strain $89 / 4762$ to mortalities of $31.1 \%$. In contrast, the control treatment and strain 89/4747 resulted in no mortalities within the experimental period. No statistical operations were performed on these data, as the differences between treatments were obvious. Results for detection of T. maritimum were consistent between treatments and with challenge results, showing high re-isolation values except in the non-pathogenic strain 89/4747 (Table 4). At the end of Day 3, water samples from all tanks were serially diluted in filtered seawater, plated onto Shieh's medium, incubated at $25^{\circ} \mathrm{C}$ for $3 \mathrm{~d}$ and then counted. The bacterial concentration of $T$. maritimum in the tanks with strains 00/3280, 89/4762 and 89/4747 was approximately $3.1 \times 10^{8}, 2.8 \times 10^{8}$ and $2.9 \times 10^{8}$ cells ml $^{-1}$, respectively.

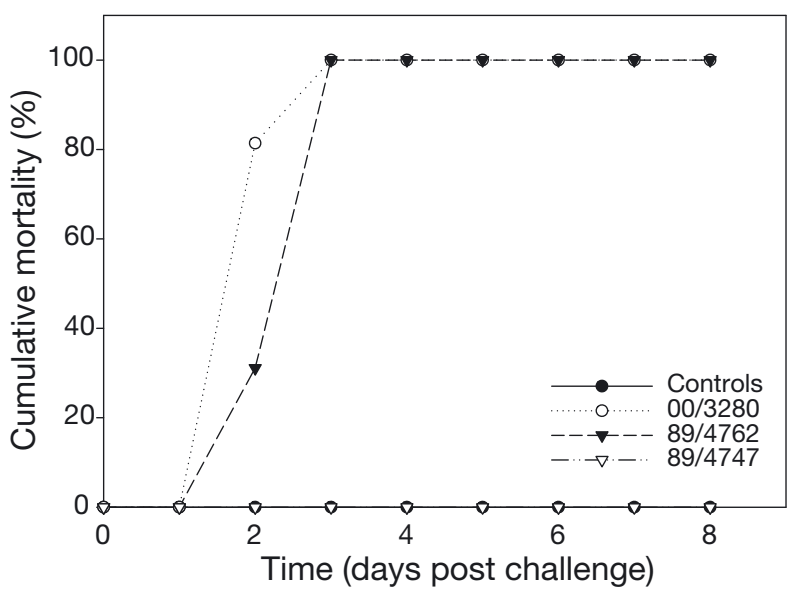

Fig. 2. Salmo salar. Expt 2. Cumulative mortality of Atlantic salmon challenged with different strains of Tenacibaculum maritimum

\section{Expt 3}

Fish challenged with the highest of 3 doses $\left(1 \times 10^{8}\right.$ cells $\left.\mathrm{ml}^{-1}\right)$ of Tenacibaculum maritimum strain 89/4762 had mortalities of $100 \%$ within $4 \mathrm{~d}$ of the commencement of the experiment (Fig. 3). The percent mortality decreased with decreasing dose size and no mortalities were recorded in the control (out) treatment. Control (in) treatment resulted in mortalities of $17 \%$; however, only 1 mortality was recorded for this treatment before Day 16, and 7 fish subsequently died within the last $5 \mathrm{~d}$ of the experiment. Kaplan-Meier survival analysis showed significant differences between curves $(\mathrm{p} \leq$ 0.0001). Pair-wise comparisons showed that significant differences occurred between the highest dose $(1 \times$ $10^{8}$ cells $\mathrm{ml}^{-1}$ ) and all other doses as well as both control treatments. There was no difference between the doses $1 \times 10^{7}$ and $1 \times 10^{6}$ cells $\mathrm{ml}^{-1}$. Similarly there was no significant difference between the $1 \times 10^{5}$ cells ml $^{-1}$ dose, controls (in) and controls (out). All other combinations were significantly different ( $p \leq 0.0033$ ). Methods used to detect the presence of $T$. maritimum showed that the bacteria could be easily re-isolated from the fish, with most of the tests achieving 100\% detection, or just below (Table 5).

\section{DISCUSSION}

Different aspects of pathogenicity were studied to compare the effects of bacterial culture conditions and virulence of strains, and to establish a model of infection.

Pathogenicity did not appear to be affected by the culture medium in which the bacteria were grown, but was affected by the presence of aeration within broth culture (Expt 1). Marine Shieh's and marine Ordal's media were the 2 growth media used previously (Carson et al. 1992, Soltani 1995, Handlinger et al. 1997) to investigate Tenacibaculum maritimum in Tasmania. Bacteria cultured from both media were able to cause infection and mortalities in Atlantic salmon Salmo salar within the $10 \mathrm{~d}$ experimental period. No significant difference in cumulative mortality was detected between the 2 media treatment groups at the end of the experimental period. Nutrient concentration is the major difference between both media, with the addition of citric acid and sodium pyruvate in marine Shieh's medium. This apparently did not significantly affect the pathogenicity of T. maritimum strain 89/4762. A comparison of MOB culture with natural seawater and synthetic 
Table 4. Tenacibaculum maritimum in Salmo salar. Expt 2. Percentage of positive results relative to the number of fish tested by media culture, Gram stain and immunofluorescence (IFAT). Lesion: $+=$ present, $-=$ absent

\begin{tabular}{|lcccc|}
\hline $\begin{array}{l}\text { Treatment } \\
\text { T. maritimum } \\
\text { strain) }\end{array}$ & $\begin{array}{c}\text { Culture (\%), } \\
\text { mean } \pm \text { SE }\end{array}$ & $\begin{array}{c}\text { Gram (\%), } \\
\text { mean } \pm \text { SE }\end{array}$ & $\begin{array}{c}\text { IFAT (\%), } \\
\text { mean } \pm \text { SE }\end{array}$ & Lesion \\
\hline $00 / 3280$ & $100 \pm 0$ & $100 \pm 0$ & $100 \pm 0$ & + \\
$89 / 4762$ & $100 \pm 0$ & $96.6 \pm 3.3$ & $100 \pm 0$ & + \\
$89 / 4747$ & $43.3 \pm 10.0$ & $23.3 \pm 10.0$ & $0 \pm 0$ & - \\
Controls & $0 \pm 0$ & $0 \pm 0$ & $0 \pm 0$ & - \\
\hline
\end{tabular}

1984) and the presence of aeration appears to allow more dispersal within the broth rather than clumping at the air-water interface, thereby producing a more homogeneous suspension. Differences in pathogenicity may simply be related to physical conditions. While care was taken to accurately estimate cell concentration using a spectrophotometer, the clumping nature of the bacteria proved problematic. Physical agitation was employed to break up aggregated material, but

seawater using strain 89/4762 (Schmidtke et al. 1991) showed no significant effect on the expression of virulence (Carson et al. 1992); however, the latter authors recommended more sensitive assay procedures to confirm this observation. They also noted the presence of adherent macroscopic clumps in broth culture made up with marine Ordal's and natural seawater. The use of artificial seawater produced a homogeneous suspension and this did not appear to affect the pathogenicity of $T$. maritimum in rainbow trout (Carson et al. 1992). In contrast, T. maritimum cultured on MOB with a limited essential inorganic ion supplement (Schmidtke et al. 1991) failed to infect fish (Carson et al. 1993). The broth using the supplement produced a more homogeneous suspension than that produced with marine Ordal's medium (Schmidtke et al. 1991). The authors speculated that there was a connection between agglutination in broth and expression of virulence factors (Carson et al. 1993).

There was an effect of aeration during bacterial culture on pathogenicity in the present study, even if the effect was not considered statistically significant. During broth culture, without aeration, the bacteria form a dense layer at the air-water interface. The addition of constant aeration encourages the development of a thinner layer of bacteria at the air-water interface with long thread-like masses moving throughout the broth as well as a fine film which became apparent on the inside flask wall. Clumping of bacteria was also evident around the aeration inlet. This phenomenon has also been observed between static and shaken cultures of Tenacibaculum maritimum isolate 89/4762, where the static culture produced fewer mortalities than the shaken culture (Soltani 1995). Tasmanian isolates produce rough suspensions; the cells aggregate into clumps rather than dispersing into a homogeneous suspension. $T$. maritimum is an obligate aerobe (Wakabayashi et al.
Table 5. Tenacibaculum maritimum in Salmo salar. Expt 3. Percentage of positive results relative to the number of fish tested by media culture, Gram stain and immunofluorescence (IFAT). Lesion: + = present, $-=$ absent. Control (in), Control (out): see Fig. 3

\begin{tabular}{|lcccc|}
\hline $\begin{array}{l}\text { Treatment } \\
(T . \text { maritimum } \\
\text { dose, cells ml }\end{array}$ & $\begin{array}{c}\text { Culture (\%), } \\
\text { mean } \pm \text { SE }\end{array}$ & $\begin{array}{c}\text { Gram (\%), } \\
\text { mean } \pm \text { SE }\end{array}$ & $\begin{array}{c}\text { IFAT (\%), } \\
\text { mean } \pm \text { SE }\end{array}$ & Lesion \\
\hline $1 \times 10^{5}$ & $100 \pm 0$ & $97.8 \pm 2.1$ & $100 \pm 0$ & + \\
$1 \times 10^{6}$ & $100 \pm 0$ & $97.8 \pm 2.1$ & $100 \pm 0$ & + \\
$1 \times 10^{7}$ & $100 \pm 0$ & $100 \pm 0$ & $100 \pm 0$ & + \\
$1 \times 10^{8}$ & $100 \pm 0$ & $100 \pm 0$ & $100 \pm 0$ & + \\
Control (in) & $100 \pm 0$ & $97.8 \pm 2.1$ & $95.6 \pm 4.3$ & + \\
Control (out) & $0 \pm 0$ & $0 \pm 0$ & $0 \pm 0$ & \\
& & & & \\
\hline
\end{tabular}


without aeration formed stickier, more cohesive cell masses while growing at the air-medium interface. These cell masses could not be broken apart during resuspension, unlike those grown with aeration. Differences between challenge doses prepared with and without aeration may simply represent differences in cell concentrations derived from the 2 different culture methods. The clumping of bacteria produced in a nonaerated broth would not expose fish to the same number of bacteria as an aerated broth even though spectrophotometric measurements appear similar. Under natural conditions it is unlikely that $T$. maritimum would clump together as they do in artificial broth culture. The artificial broth culture demonstrates the sticky nature of the bacteria, which under natural conditions might be of benefit in attachment to the host, rather than to each other.

We suggest that the adhesive nature of the bacteria is associated with pathogenicity and virulence. The virulent strains 89/4762 and 00/3280 were highly adherent to the agar in initial culture and produced a highly aggregated suspension in broth culture. Strain 89/4747 was easy to remove from agar plates and also produced a far more homogeneous suspension in broth. This phenomenon has also been noted by others (Carson et al. 1992, 1993, Soltani 1995) who, like the present study, suggest that this 'sticky' clumping nature may facilitate an adhesion mechanism that plays a role in the pathogenicity of Tenacibaculum maritimum. Attachment to the host is an important first step in the disease process (Ofek \& Doyle 1994) and would allow proliferation on the host tissue and facilitate dispersal of any toxin the bacterium produces. The stickier the isolate, the more virulent it is likely to be, as it would be more adherent to the host. Stickiness would not be the only virulence factor, but on the basis of what has been found in the present study, it is an extremely important one that requires greater attention.

Also of interest was the effect that the anaesthetic, clove oil, had on the re-isolation of Tenacibaculum maritimum. The use of culture was far less sensitive than Gram staining and IFAT, with little or no bacterial growth on many plates for Expt 1, in which clove oil was used as an anaesthetic. It was not only the absence of T. maritimum colonies on the plates but also a lack of growth of bacteria that was interesting. Chemical components of anaesthetics could potentially kill off bacteria if the dosage is too high or the exposure time too long. This problem has been observed with field investigations of T. maritimum in farmed salmonids (J. Carson pers. comm). A subsequent decrease in dosage $\left(0.025 \mathrm{ml} \mathrm{l}^{-1}\right.$ seawater $)$ and time $(<2 \mathrm{~min})$ in the anaesthetic provided better and more consistent results in Expts 2 and 3. The use of carbon dioxide or another non-chemical anaesthetic may be more suitable to ensure better isolation of T. maritimum.

Expt 2 was undertaken to observe differences in the pathogenicity of strains. Strain 89/4747 was non-pathogenic, causing no infection or mortalities throughout the experimental period, which is consistent with the findings of Powell et al. (2004). Interestingly, Carson et al. (1992) described this strain as highly virulent, with all fish becoming infected and developing lesions, including controls. All fish were kept in a single flowthrough tank and were identified using branding and tagging techniques (Carson et al. 1992). The high level of infectivity was suggested to be the result of the use of a single tank, insufficient water turnover and a virulent strain (Carson et al. 1992). Anecdotal evidence from the present study suggests that attenuation occurs quickly in Tenacibaculum maritimum isolates (R. van Gelderen unpubl.). The cause of the non-pathogenic results of strain 89/4747 in the present study may be attenuation, but this requires further investigation as there are many other factors to consider, such as preservation techniques, age of isolate, culture media and storage over time (Michel \& Garcia 2003, O'Keefe et al. 2006).

In contrast, strains 00/3280 and 89/4762 were highly virulent, resulting in $100 \%$ mortalities in $3 \mathrm{~d}$. Both strains have previously been demonstrated as highly pathogenic (Carson et al. 1992, Handlinger et al. 1997, Powell et al. 2004). Experimental application of Tenacibaculum maritimum to the gills of Atlantic salmon using strain 00/3280 caused high levels of mortalities within $48 \mathrm{~h}$ (Powell et al. 2004). Strain 89/4762 was highly pathogenic in rainbow trout and Atlantic salmon when challenged by immersion (Carson et al. 1992, Soltani 1995, Handlinger et al. 1997). The study undertaken by Soltani (1995) also noted that strains of T. maritimum could be host-specific and found that a strain isolated from mullet Aldrichetta forsteri did not cause disease in Atlantic salmon. In the present study, Strain 00/3280 (from rainbow trout) was highly virulent in Atlantic salmon but as both are salmonids, cross-species susceptibility was more likely.

The virulence of these strains needs to be put into perspective. The available experimental systems for the initial experiments were semi-static, with a full water change every $24 \mathrm{~h}$. Water used during these experiments was filtered down to $0.8 \mu \mathrm{m}$. The inoculum was approximately $1 \times 10^{7}$ cells $\mathrm{ml}^{-1}$. After $3 \mathrm{~d}$ (when mortalities had reached $100 \%$ in 2 groups), the concentration of Tenacibaculum maritimum cells was determined to be $3.1 \times 10^{8}$ cells $\mathrm{ml}^{-1}$ for strain $00 / 3280$ and $2.8 \times 10^{8}$ cells ml $^{-1}$ for strain $89 / 4762$ per tank. It is possible that the fish were subjected to an increasing dose over time, which may have contributed to the high mortality rate observed. Semi-static conditions 
would have assisted in the attachment of the pathogen to the host by providing greater opportunity for contact with the host. However, all strains were under the same conditions and therefore virulence differences can be observed. The semi-static conditions would also account for the high levels of mortality (68.75 to 93.75\%) observed in Expt 1 (comparison of culture methods). However, mortalities did not reach $100 \%$ in Expt 1; this was probably due to a colder water temperature and a less dense fish population (Table 2) (Carson et al. 1992, Soltani 1995).

Expt 3, a comparison of different doses of strain 89/4762 of Tenacibaculum maritimum, was carried out to develop a model of infection. It is difficult to compare the present findings with other pathogenicity investigations, due to differences in routes of challenge, size of fish and inoculum dose. What is apparent is that a challenge model of infection has been established for Atlantic salmon. The present study results are further supported by the work of Soltani (1995), who produced a similar model of infection for Atlantic salmon at the same salinity and similar temperatures.

A model of infection has been established in turbot Scophthalmus maximus using immersion (AvendañoHerrera et al. 2006). Fish weighing 4 to $6 \mathrm{~g}$ required $18 \mathrm{~h}$ of inoculum $\left(5 \times 10^{3}\right.$ to $\left.5 \times 10^{8} \mathrm{cells} \mathrm{ml}^{-1}\right)$ exposure time to generate a successful infection. The authors reported that they were unable to infect turbot with only a 1 or $2 \mathrm{~h}$ bath. The immersion challenge was repeated with 15 to $20 \mathrm{~g}$ fish and similar findings were noted. They suggested that the exposure time is not sufficient for the development of a biofilm on the skin/gills, which is required for successful infection. In contrast, the present study, Carson et al. (1992) and Soltani (1995) only required a $1 \mathrm{~h}$ bath to produce an infection using challenge inoculum within the same range as Avendaño-Herrera et al. (2006). This could be the result of either using a more virulent strain or of the fact that, in the present study, salmonids were more susceptible to Tenacibaculum maritimum than turbot. Salmonids are competitive and will bite and harass each other when held in captivity (Mork et al. 1999, MacLean et al. 2000). The observed size difference of fish in each experiment would have contributed to this behaviour, which is likely to facilitate bacterial invasiveness, as damage to the epithelium would create a portal of entry for the bacteria to colonise and proliferate (Handlinger et al. 1997).

Other successful methods of inducing marine flexibacteriosis are usually associated with direct application to various areas of the body and scarification by different means (Masumura \& Wakabayashi 1977, Wakabayashi et al. 1984, Baxa et al. 1987, Carson et al. 1992, Bernardet et al. 1994, Powell et al. 2004). While intraperitoneal and intramuscular injections are inef- fective (Campbell \& Buswell 1982, Baxa et al. 1987, Carson et al. 1992), subcutaneous injection has worked on occasion, which is probably a result of injecting into the dermal layer, where bacteria are found in natural outbreaks (Masumura \& Wakabayashi 1977, Wakabayashi et al. 1984, Alsina \& Blanch 1993, Bernardet et al. 1994, Soltani 1995, Avendaño-Herrera et al. 2006). As Tenacibaculum maritimum is an external pathogen, the conditions within the peritoneal cavity (intraperitoneal injection) and muscle (intramuscular injection) do not support the growth and proliferation of the bacterium. It appears as though in some fish species direct contact is required between T. maritimum and host so that attachment and proliferation can occur.

From the work of Carson et al. (1992) it was apparent that horizontal transmission occurred, and in the present study as well as in Soltani (1995), controls were kept separate from the main system, even using a separate biofilter system. In the present study another set of controls was used within the system to evaluate the level of horizontal transmission. The system was set up with a filter bank down to $0.8 \mu \mathrm{m}$ for incoming water and 2 UV lights to reduce bacterial load. After $16 \mathrm{~d}$, fish with lesions appeared and consequently some mortalities occurred. Considering the experiment only lasted $21 \mathrm{~d}$, and $3 \mathrm{~d}$ of no mortalities had to occur before terminating the experiment, the level of horizontal transmission was relatively low.

Investigations into the pathogenicity of Tenacibaculum maritimum in Atlantic salmon have provided more insight into the nature of the disease. There appears to be a relationship between virulence and the 'clumping' of the bacteria, which requires further study. Two of the 3 strains tested were highly pathogenic and could cause mortalities with a $1 \mathrm{~h}$ bath immersion. The lack of pathogenicity in strain 89/4747 in the present study is also worthy of greater attention, since in previous studies it was described as highly pathogenic. The most conclusive part of the present study is that a model of infection has been established that can be used in future studies.

\section{LITERATURE CITED}

Alcamo IE (1983) Fundamentals of microbiology. Addison Wesley, Boston, MA

Alsina M, Blanch AR (1993) First isolation of Flexibacter maritimus from cultivated turbot (Scophthalmus maximus). Bull Eur Assoc Fish Pathol 13:157-160

Anacker RL, Ordal EJ (1959) Studies on the myxobacterium Chondrococcus columnaris. I. Serological typing. J Bacteriol 78:25-32

> Avendaño-Herrera R, Toranzo AE, Magariños B (2006) A challenge model for Tenacibaculum maritimum infection in turbot, Scophthalmus maximus (L.). J Fish Dis 29: $371-374$ 
Baxa DV, Kawai K, Kusuda R (1987) Experimental infection of Flexibacter maritimus in black sea bream (Acanthopagrus schlegeli) fry. Fish Pathol 22:105-109

Bernardet JF, Campbell AC, Buswell JA (1990) Flexibacter maritimus is the agent of 'black patch necrosis' in Dover sole in Scotland. Dis Aquat Org 8:233-237

Bernardet JF, Kerouault B, Michel C (1994) Comparative study on Flexibacter maritimus strains isolated from farmed sea bass (Dicentrarchus labrax) in France. Fish Pathol 29:105-111

Campbell AC, Buswell JA (1982) An investigation into the bacterial aetiology of 'black patch necrosis' in Dover sole, Solea solea L. J Fish Dis 5:495-508

Carson J, McCosh P, Schmidtke L (1992) Pathogenicity of Flexibacter maritimus in rainbow trout. In: Valentine P (ed) Barriers and breakthroughs: proceedings of the SALTAS research review seminar. Salmon Enterprises of Tasmania, Dover, p 89-99

Carson J, Schmidtke L, McCosh P (1993) A salmonid vaccine against Flexibacter maritimus-dream or reality? In: Valentine P (ed) Seeking and solving: papers from the SALTAS research and development review seminar. Salmon Enterprises of Tasmania, Dover, p 113-120

Chen MF, Henry-Ford D, Groff JM (1995) Isolation and characterization of Flexibacter maritimus from marine fishes of California. J Aquat Anim Health 7:318-326

Devesa S, Barja JL, Toranzo AE (1989) Ulcerative skin and fin lesions in reared turbot, Scophthalmus maximus (L.). J Fish Dis 12:323-333

Handlinger J, Soltani M, Percival S (1997) The pathology of Flexibacter maritimus in aquaculture species in Tasmania, Australia. J Fish Dis 20:159-168

Howard T (1995) Media and methods manual. Fish Health Unit, Department of Primary Industries, Launceston, TAS

Johnson AM, Munday BL (1993) Toxoplasmosis: pathology, histopathology and serology. In: Corner LA, Bagust TJ (eds) Australian standard diagnostic techniques for animal diseases. Commonwealth Scientific and Industrial Research Organisation Publications, Melbourne, VIC

Kusuda R, Kawai K (1998) Bacterial diseases of cultured marine fish in Japan. Fish Pathol 33:221-227

MacLean A, Metcalfe NB, Mitchell D (2000) Alternative competitive strategies in juvenile Atlantic salmon (Salmo salar): evidence from fin damage. Aquaculture 184: 291-302

Madigan MT, Martinko JM (2003) Brock biology of microorganisms. Pearson Prentice Hall, Upper Saddle River, NJ

Editorial responsibility: David Bruno, Aberdeen, UK
Masumura K, Wakabayashi H (1977) An outbreak of gliding bacterial disease in hatchery-born red sea bream (Pagrus major) and gilthead (Acanthopagrus schlegeli) fry in Hiroshima. Fish Pathol 12:171-177

Michel C, Garcia C (2003) Virulence stability in Flavobacterium psychrophilum after storage and preservation according to different procedures. Vet Res 34:127-132

Mork OI, Bjerkeng B, Rye M (1999) Aggressive interactions in pure and mixed groups of juvenile farmed and hatcheryreared wild Atlantic salmon Salmo salar L. in relation to tank substrate. Aquacult Res 30:571-578

O'Keefe KJ, Morales NM, Ernstberger H, Benoit G, Turner PE (2006) Laboratory-dependent bacterial ecology: a cautionary tale. Appl Environ Microbiol 72:3032-3035

Ofek I, Doyle RJ (1994) Bacterial adhesion to cells and tissues. Chapman \& Hall, New York, NY

Ostland VE, LaTrace C, Morrison D, Ferguson HW (1999) Flexibacter maritimus associated with a bacterial stomatitis in Atlantic salmon smolts reared in net-pens in British Columbia. J Aquat Anim Health 11:35-44

Pazos F, Santos Y, Macias AR, Núñez S, Toranzo AE (1996) Evaluation of media for the successful culture of Flexibacter maritimus. J Fish Dis 19:193-197

Powell M, Carson J, van Gelderen R (2004) Experimental induction of gill disease in Atlantic salmon Salmo salar smolts with Tenacibaculum maritimum. Dis Aquat Org 61: 179-185

Schmidtke L, Carson J, Howard T (1991) Marine Flexibacter infection in Atlantic salmon - characterisation of the putative pathogen. In: Valentine P (ed) Proceedings of the SALTAS research review seminar. Salmon Enterprises of Tasmania, Dover, p 25-39

Soltani M (1995) Comparison of some physiological variables of four species of Cytophaga/Flexibacter-like bacteria (CFLB) and the pathogenesis and chemotherapy of disease caused by some of these pathogens. PhD dissertation, University of Tasmania, Launceston

van Gelderen R (2007) Vaccination of Atlantic salmon against marine flexibacteriosis. PhD dissertation, University of Tasmania, Launceston

Wakabayashi H, Hikida M, Masumura K (1984) Flexibacter infection in cultured marine fish in Japan. Helgol Meeresunters 37:587-593

Wakabayashi H, Hikida M, Masumura K (1986) Flexibacter maritimus sp. nov. a pathogen of marine fishes. Int J Syst Bacteriol 36:396-398

Submitted: October 28, 2009; Accepted: March 6, 2010 Proofs received from author(s): August 11, 2010 